Original Research Paper

\title{
Effects of Some Environmental Stresses on Bio Indicators and Population Densities of Glomus mossae Fungi Associated with Wheat (Triticum aestivum L.) Crop
}

\author{
Ali Jabbar Abdulsada, Sadeq J.H. Dwenee, Naeem Saeed Dheyab, Wafaa Hadi Hasoon, \\ Doaa Abass Hanon, Bara Hassan Hamza and Hadi Mahdi Aboud \\ Agric. Research Directorate, Ministry of Science and Technology, Baghdad, Iraq
}

\author{
Article history \\ Received: 28-07-2019 \\ Revised: 24-10-2019 \\ Accepted: 19-03-2020 \\ Corresponding Author: \\ Ali Jabbar Abdulsada \\ Agric. Research Directorate, \\ Ministry of Science and \\ Technology, Baghdad, Iraq \\ Email: alijabbar70@yahoo.com
}

\begin{abstract}
Field experiment was conducted to determine the effect of soil salinity and Fusariume germanium on population of Glomus mossae Fungi within root of wheat as manifested by the fungal spore's number, density infection and the percentage of infected root by Glomus mossae. The results didn t show effect the environmental stresses on comparability reproductive for Glomus mossae fungi associated with wheat crop. The results significant increase $(P=0.05)$ in average of spores number, intensity infection and the percentage of infected root (43.00, 60.8 and 72.67) by Glomus mossae treatment. A significant increasing happened in the percentage of germination seed of wheat with Glomus mossae fungi in soil Electric conductivity $2.64 \mathrm{dS} / \mathrm{m}^{-1}$ was $(75.7 \%$, chlorophyll content 32.33 spad and plant height $40.00 \mathrm{~cm}$ ) compared with treatment infection Fusariume germanium fungi in the soil with Electric conductivity 14.5 $\mathrm{dS} / \mathrm{m}^{-1}$ since the ratio of germination was $(24.3 \%$, chlorophyll content in the plant $13.67 \mathrm{spad}$ and height plant $12.00 \mathrm{~cm})$. On the other hand the results recorded a significant increasing in macronutrient $(\mathrm{N}, \mathrm{P}$ and $\mathrm{K} \%$ ) by Glomus mossae treatment which recorded (2.567, 0.272 and $2.283 \%$ ) respectively compared with treatment infection Fusariume germanium fungi $(1.7,0.100$ and $1.800 \%)$ respectively. Interaction treatment showed a significant increasing by Glomus mossae treatment with soil Electric conductivity $14.5 \mathrm{dS} / \mathrm{m}^{-1}$ in terms of fungal spores number, density infection and the percentage of infected root of Glomus mossae (55.00, 75.7 and 93.00) respectively compared with treatment infection Fusariume germanium fungi with soil Electric conductivity $2.64 \mathrm{dS} / \mathrm{m}^{-1}(19.33,13.00$ and 52.33) respectively. Finally the results showed a significant increasing interaction by Glomus mossae treatment with soil Electric conductivity 2.64 $\mathrm{dS} / \mathrm{m}^{-1}$ in the (ratio of germination $75.7 \%$, chlorophyll content in the plant 32.33 spad and height plant $40.00 \mathrm{~cm}$ ) compared with treatment infection Fusariume germanium fungi with soil Electric conductivity $14.5 \mathrm{dS} / \mathrm{m}^{-1}$ (24. 3, 13.67 and 12.00) respectively.
\end{abstract}

Keywords: Fungus Glomus mossae, Triticum aestivum, Salinity, Fusariume germanium

\section{Introduction}

Wheat (Triticum aestivum L) is belong to Cereals plants, which represent the most world's strategic crops in terms of its daily consumption and food importance (Hassan, 1999). During the growing season, this crop is exposed to many biotic and abiotic stresses (Levitt,
1980). The most important biotic stress is the pathogenesis of the Fusariume species which are considered to be one of the most common species of Fusariume wilt disease affecting vegetable plants, Crops and ornamental plants (Bogale, 2006). Fusariume species cause a significant decline in the productivity of crops in many countries of world (Agrios, 2005) which 
is one of the most serious fungal diseases affecting plants due to suit their growth in environmental conditions that prevailing in the region where the farmers has to apply many chemical pesticides in order to reduce its severity. This work would be useful for revealing the numerous fungal strains that are not affected by chemical pesticides, although they are used at high concentrations and contribute to environmental pollution and human health (Alimi and Ayawale, 2014). Due to hazards use of chemical pesticides, Global attention has focused on the search for methods of biocontrol using bacteria and beneficial fungi as biocontrol agents. Several recent studies have indicated that Glomus mossae vaccines have a significant effect on the growth of wheat plant and in the control of fungal diseases that affect this crop. The Glomus mossae are characterized by the production of high plant growth promotion such as IAA, Cytokinin and GA3 which excreted in rhizosphere and transferred to plant tissues through the symbiotic relationship with microorganisms (Siddiqui et al., 2006). As well as its ability to secrete Glomalin, which works to enhance soil structure, this improves the ability to hold water for a long time (Adeleke and Odedeji, 2010). It has been found that the Glomus mossae have significant impact in reducing the infection of endemic pathogens in soil (Naseby et al., 2000). Salinity is one of the problems impediment agricultural production and salt-affected soils are widespread in large parts of the world, accounting for more than one-third of the world's irrigated land (Lauchli and Epstein, 1990) and studies have shown that plants infected with Glomus mossae are more resistant to abiotic stress conditions such as salinity, drought and toxicity with heavy metals (Miransari, 2011). Many studies confirm that plants infected with Glomus mossae under saline stress conditions increase the accumulation of amino acid prolin in maize and wheat yield due to the activation of the P5CS gene responsible for prolin production in cells as a response to stresses (Sheng et al., 2008; Azad et al., 2012; Salman, 2013). The aim of this study was to determine the effect of salinity and Fusariume germinearum on population of Glomus mossae associated with wheat crop.

\section{Materials and Methods}

\section{Preparation of Fungi Disease Isolation}

Fusarum graminearum has been isolated from the equipment of the Laboratory of Plant Diseases, which belong to the Integrated Control Center/directorate of Agricultural Research/Ministry of Science and Technology (formerly). The fungi were prepared using natural media of wheat seeds which were soaked for $24 \mathrm{~h}$ in tap water. The seeds were then distributed in $250 \mathrm{~mL}$ conical flask with $100 \mathrm{~g}$ per flask which was sterilized by autoclave with $20 \mathrm{~min}$ at $121^{\circ} \mathrm{C}$ and 1.5 bar pressure and 2 for 2 days. It was then inoculated with $0.5 \mathrm{~cm}$ disease fungi tablets and incubated at $25^{\circ} \mathrm{C}$ for two weeks with daily manual shaking to avoid coagulation of mixture (Bovill, 2007).

\section{Preparation of Glomus Mossae}

The isolates of (Glomus mossae) were obtained from fungal parts (infected roots + spores + mycelium). These structures were mixed with a certain amount of sterilized compost and the fungal fungus was calculated according to the method described by (Kormanik et al., 1980).

\section{Field Experiment}

A field experiment was carried out during 2014-2015 in the Agricultural Research Directorate-Ministry of Science and Technology (30 km southeast of Baghdad) where two equal plots of land were selected for cultivation with two meters separation between the two parts. Soil of first plot was replaced by alluvial soil with Electrical Conductivity (EC) $14.5 \mathrm{dS} / \mathrm{m}^{-1}$ of $30 \mathrm{~cm}$ of upper soil layer. The (EC) of second plot soil was $2.64 \mathrm{dS} / \mathrm{m}^{-1}$. Soil samples were taken for analysis in the laboratory (Table 1). The population density of Glomus mossae in soil was 10/gm soil. Experiment was plowed and grazed with disk compartments. The field was then settled and divided into $1 \times 1 \mathrm{~m}^{2}$ plots. Each plot consisted of five lines with one meter long for each treatment, the distance between the plots $20 \mathrm{~cm}$. The land was divided into three main sectors, separated by a distance of $1 \mathrm{~m}$. In order to reduce lateral water movement between the plots, polyethylene was inserted in soil around each separated plot for $0.25 \mathrm{~m}$ depth. The experimental were 48 units. Wheat seed (Cham type) planted at $160 \mathrm{~kg} / \mathrm{ha}$. The inoculum was added to seeds according to pad method. The following treatments were conducted in fields with three replicates: Wheat seeds without inoculums as a (control treatment), seeds inoculated with Glomus mossae (G), seeds infected with Fusariume graminearum (F), wheat seeds treated with Glomus mossae fungi + fusaruim Graminearum (GF) under two levels of soil salinity $\left(2.64 \mathrm{dS} / \mathrm{m}^{-1}\right.$ and $\left.14.5 \mathrm{dS} / \mathrm{m}^{-1}\right)$.

\section{Calculation of Number of Spores, Intensity and Percentage of Infection of Glomus Mossae}

The decanting wet sieving method described by Gerdeman and Nicolson (1963) was used. Samples were taken from soil around the roots of the wheat plant at $10 \mathrm{~g}$ at the end of experiment. The suspension containing spores were transferred to a glass baker, diluted to $250 \mathrm{~mL}$ was placed. The suspension in $50 \mathrm{~mL}$ plastic tubes and place in the centrifuge at $4000 \mathrm{rpm}$ for $5 \mathrm{~min}$. Minutes (without adding sucrose solution) to facilitate the collection of spores at surface of suspension and then withdraw $1 \mathrm{~mL}$ and transfer to the nematode count slice to calculate the spore rate in $1 \mathrm{~mL}$ of suspension and for the purpose of calculating the number of spores in $10 \mathrm{~g}$ soil followed the equation set by Gaur and Adholya (1994). 


\section{Number of Spores Per $10 \mathrm{~g}$ Soil = Rate of Spores Counting in $1 \mathrm{~mL} \times$ Final Size of Suspension}

The disease incidence and severity of Glomus mossae fungi was calculated according to the method described by Phillips and Hyman (1970) by taking $50 \mathrm{~g}$ of dried rizosphere soil. Hardness was resolved on the premise that the cells of the root cortex did not hold color, whereas fungal cell walls maintained the dye even after it was shortened. The method is to extract the root mass of the plants and gently wash them with running water to get rid of the suspended dust and then in a preservative solution made of formalin: Acetic acid: ethanol $(13 \mathrm{~mL}$ of formalin, 5 of acetic acid and $200 \mathrm{~mL} / 50 \%$ of ethanol). Cut the roots into little pieces $(1 \mathrm{~cm})$ by 10 pieces/plants placed in glass bottles size $20 \mathrm{~mL}$ and added a $10 \%$ of $\mathrm{KOH}$ solution and placed in a water bath at a temperature of $70^{\circ} \mathrm{C}$ for 15 , the roots were extracted and washed with distilled water after placed in a sieve (60 mesh), the roots were then transferred by using forceps to Petri dishes with hydrogen peroxide solution treated $1 \%$ at room temperature for 10 minutes. The roots were then washed thoroughly with distilled water and then treated with $1 \% \mathrm{HCl}$ solution for $3 \mathrm{~min}$. The roots were transferred to $100 \mathrm{~mL}$ glass bottles supplied with Acid Fochsin, which was prepared according to the method described previously, by mixing $63 \mathrm{~mL}$ of Glycerol +875 $\mathrm{mL}$ of lactose +63 distilled water $+0.1 \mathrm{~g}$ of Fochsin pigment, the roots were treated within $30 \mathrm{~min}$ heat $70 \mathrm{~m}$ in a water bath, the root pieces were then extracted and arranged on a glass slide of 10 pieces/slide where they were examined under the microscope (Kormanik et al., 1980). The intensity of the infection according to (Dheyab, 2013) equation was calculated and the following gradient was used to measure the intensity of the injury; $0=$ no injury, $1=25 \%$ of the root total is infected, $3=26-50 \%$ of the root total is infected, $3=51-75 \%$ of the root total is infected and $5=76-100 \%$ of the root total is infected.

The intensity of infection of Glomus mossae according to the equation (Mckinney, 1923) was calculated as follows:

\section{Intensity of infection \\ $=\frac{\text { Total (number of infected pieces } x \text { degree of injury) }}{\text { total number of examed } x \text { Highest degree of injury }}$ $=\frac{\text { total number of examined } \times \text { Highest degree of injury }}{}$}

The infection percentage was calculated by the formula described by (Giovannetti and Mosse, 1980):

$$
\begin{aligned}
& \text { Percentage of Glomus mossaeinfection } \\
& =\frac{\text { Number of infected root pieces }}{\text { Total number of examined root parts }} \times 100
\end{aligned}
$$

The rate of seedling germination was calculated on the surface land after 14 days of cultivation in the field. Chlorophyll content was measured at the time of spike production by a chlorophyll-based chlorophyll content control device (CCM-200) of US origin and OPTI-
SCIENCES manufacturer. The content of leaves randomly was measured for 3 plants in three replicates of each treatment. Plant height was measured at the end of the experiment using a measuring tape and wheat plants were cut off after four months from the date of cultivation. The leaf content of the nitrogen, phosphorus and potassium component was measured according to (Labetowicz, 1988).

The experiment was carried out in accordance with the RCBD design and three replicates for each treatment and the data was analyzed according to the program. Genstat was compared with the Least Significant Difference (L.S.D) at the probability level (0.05) (Mohammedi and Al-Mohammadi, 2012).

\section{Results and Discussion}

The results of Tables 1 to 3 showed that the number of fungal spores per gm soil and the intensity of infection by Glomus mossae and the percentage of infected roots varied with the variability of soil EC. The results showed a significant increase in number of Glomus mossae spores per gm soil and intensity of infection by Glomus mossae and percentage of infected roots in plants that inoculated with Glomus mossae (43.00 spores/gm soil, $60.8 \%$ and $72.67 \%$ ) compared with the treatment of infection with Fusariume (22.67 spores/gm soil, $13.2 \%$ and $36.00 \%$ ) respectively. The increase in both the number of Glomus mossae spores and the intensity of infection and the percentage of infection of the microorganisms in the inoculated wheat plants increases the density of the inoculate (spore, hypha, infected root) compared to the plants infected with Fusariume. There is a decrease in the percentage and intensity of infection of bean root with Glomus mossae this may be due to competition of microorganisms with the pathogenesis on root secretions in the razosphere and competition is significant when there is more than one type of fungus in the area of the razosphere. The results showed a significant increase in number of Glomus mossae spores/gm soil and intensity of infection by Glomus mossae and percentage of infected roots for soil with $14.5 \mathrm{dS} . \mathrm{m}^{-1}$ by (35.5 spores/gm soil, $48.5 \%$ and $59.83 \%$ ) respectively compared to plants grown in soil with $2.64 \mathrm{dS} . \mathrm{m}^{-1}$ (23.83 spores/gm soil $29 \%$ and $39.92 \%)$ respectively. The treatment of interaction between plants infected with Glomus mossae and salinity showed the highest number of Glomus mossae spores, the intensity of infection by Glomus mossae and the percentage of infected roots (55.00 spores/gm soil, 75.7\%, 93.00\%) compared to the treatment of Fusariume infected plants and soil with EC 2.64 dS.m ${ }^{-1}$ (19.33 spores/gm soil and 13.0\%). The percentage of infected roots in soil with EC 14.5 $\mathrm{dS} . \mathrm{m}^{-1}$ was $32.67 \%$. This may be attributed to the roots of plants that are subject to environmental stress such as drought and salinity. The fungus increases the internal hypha and the vesicular within the roots to cope with these conditions (Siddiqui et al., 2006). 
Table 1: Some chemical and physical properties of the studied soil samples

\begin{tabular}{|c|c|c|c|c|c|c|c|}
\hline \multirow[b]{2}{*}{ Property } & \multicolumn{2}{|l|}{ Value } & \multirow[b]{2}{*}{ Unit } & \multicolumn{4}{|c|}{ Texture $\mathrm{gm} \cdot \mathrm{kg}^{-1}$} \\
\hline & $\begin{array}{l}\text { Soil with EC } \\
2.64 \text { dS.m }{ }^{-1}\end{array}$ & $\begin{array}{l}\text { Soil with EC } \\
14.5 \text { dS.m }{ }^{-1}\end{array}$ & & $\begin{array}{l}\text { Soil with EC } \\
2.64 \mathrm{dS} . \mathrm{m}^{-1}\end{array}$ & & $\begin{array}{l}\text { Soil with EC } \\
14.5 \text { dS.m }{ }^{-1}\end{array}$ & \\
\hline $\mathrm{PH}(1: 1)$ & 7.2 & 7 & ------------ & 600 & sand & 424 & sand \\
\hline $\mathrm{N}$ & 9.5 & 9 & mg. $\mathrm{Kg}^{-1}$ & 200 & caly & 288 & caly \\
\hline Ava. P & 30.62 & 25.82 & & 100 & silt & 288 & silt \\
\hline Ava. K & 210.46 & 260.48 & & Sand & & Clay loam & \\
\hline $\mathrm{Ca}$ & 226.11 & 543.66 & & & & & \\
\hline $\mathrm{Cl}$ & 274.27 & 2938.59 & & & & & \\
\hline $\mathrm{SO}_{4}$ & 1200.03 & 3271.14 & & & & & \\
\hline $\mathrm{Mg}$ & 76.73 & 266.3 & & & & & \\
\hline $\mathrm{Na}$ & 292.05 & 3526.47 & & & & & \\
\hline
\end{tabular}

Table 2: Effect of Fusariume and Glomus mossae infection and soil salinity on average number of Glomus mossae spores/gm soil

\begin{tabular}{llll} 
Treatments $\backslash$ Soil EC $\left(\mathrm{dS} . \mathrm{m}^{-1}\right)$ & $2.64 \mathrm{dS} / \mathrm{m}^{-1}$ & $14.5 \mathrm{dS} / \mathrm{m}^{-1}$ & Mean treatments \\
\hline Control & 21 & 28.00 & 24.50 \\
F & 19.33 & 26.00 & 22.67 \\
G & 31 & 55.00 & 43.00 \\
FG & 24 & 31.67 & 27.83 \\
Mean soil salinity & 23.83 & 35.17 & \\
\hline
\end{tabular}

$\mathrm{F}=$ Fusaruim graminearum $\mathrm{G}=$ Glomus mossae fungi

$\mathrm{FG}=$ Fusaruim graminearum + Glomus mossae fungi

L.S.D treatment $=1.218$ L.S.D soil salinity $=1.722$

$\mathbf{2 . 4 3 6}=\mathrm{D}$ interactions .S.L

Table 3: Effect of Fusariume and Glomus mossae infection and soil salinity on Glomus mossae infection intensity

\begin{tabular}{llll}
\hline Treatments $\mid$ Soil EC $\left(\mathrm{dS} . \mathrm{m}^{-1}\right)$ & $2.64 \mathrm{dS} / \mathrm{m}^{-1}$ & $14.5 \mathrm{dS} / \mathrm{m}^{-1}$ & Mean treatments \\
\hline Control & 31.0 & 52.7 & 41.80 \\
F & 13.0 & 13.3 & 13.20 \\
G & 46.0 & 75.7 & 60.80 \\
FG & 25.7 & 52.7 & 39.20 \\
Mean soil salinity & 29.0 & 48.5 & 38.75 \\
\hline
\end{tabular}

$\mathrm{F}=$ Fusaruim graminearum $\mathrm{G}=$ Glomus mossae fungi

$\mathrm{FG}=$ Fusaruim graminearum + Glomus mossae fungi

L.S.D treatment $=6.64$ L.S.D soil salinity $=4.69$

L.S.D interaction $=9.38$

The results in Tables 5 to 7 show refers to the significant superiority of plant that inoculated with Glomus mossae in percentage of seed germination, chlorophyll content and plant height $(73.3 \%, 28.17$ spad and $32.50 \mathrm{~cm})$ respectively, compared to the treatment of infection with Fusariume $(26.3 \%, 14.00$ spad and $12.33 \mathrm{~cm})$ respectively. Above showed significant superiority in the studied parameters of plants growing in soil with a EC $2.64 \mathrm{dS} . \mathrm{m}^{-1}$ $(56.2 \%, 21.11$ spad and $24.00 \mathrm{~cm})$ respectively compared to soil with EC $14.5 \mathrm{dS} . \mathrm{m}^{-1}(52.7 \%, 18.25$ spad and 18.25 $\mathrm{cm}$ ) for percentage of seed germination, chlorophyll content and plant height respectively. The treatment of interaction between Glomus mossae and soil EC 2.64 dS.m ${ }^{-1}$ were significantly higher with percentage of seed germination, chlorophyll content and plant height of $(75.7 \%, 32.33 \mathrm{spad}$ and $40.00 \mathrm{~cm}$ ) respectively compared to the interaction between the Fusariume and soil with EC $14.5 \mathrm{dS}^{-1} \mathrm{~m}^{-1}$ of $(24.3 \%, 13.67 \mathrm{spad}$ and $12.00 \mathrm{~cm})$ for seed germination, chlorophyll content and plant height respectively, which did not differ significantly from control treatment with EC 2.64 $\mathrm{dS} . \mathrm{m}^{-1}$. The results in Tables 8 to 10 show a significant superiority for plants inoculated with Glomus mossae in parameters of plant concentration of nitrogen, phosphorus and potassium $(2.567 \%, 0.272 \%$ and $2.833 \%)$ respectively compared with treatment of inoculate with Fusariume by $(1.7,0.10$ and 1.80$)$ respectively. The plant grown in soil with EC $2.64 \mathrm{dS} . \mathrm{m}^{-1}$ showed significant superiority by $(2.442 \%, 0.236 \%$ and $2.700 \%)$ respectively compared to soil with EC 14.5 dS.m ${ }^{-1}$ (1.700, 0.136 and $\left.1.867 \%\right)$ for plant concentration of nitrogen, phosphorus and potassium respectively. The interaction between Glomus mossae and soil with EC $2.64 \mathrm{dS} . \mathrm{m}^{-1}$ showed significant superiority by $(3.233 \%, 0.326 \%$ and $3.500 \%)$ while interaction between Fusariume and the soil with EC $14.5 \mathrm{dS} . \mathrm{m}^{-1}$ was lowest value by $(1.367 \%, 0.046 \%$ and $1.333 \%)$ for plant concentration of nitrogen, phosphorus and potassium respectively. The increase in the number of Glomus mossae spores in Tables 2 to 4 leads to an increase in the number of 
root hairs, which has helped to spread the root mass and produce growth hormones such as Gibberellin, Auxins, Cytokines, Amino acids and Hormones, which increase the growth and expansion of cells and tissues, which reflected positively on the percentage of germination (Table 5), especially Gibberellin, which causes the important act of Gibberellic acid in formation of hydrolysis enzymes (amylase, protease and lipase) in seeds which leads to form the simple materials of sugars, amino acid and lipids that would release required energy to emerge the seeds (Bharathi et al., 2004) encourage the production of soluble phenols and carbohydrates that have a role in maintaining the integrity of the chloroplast and thus increasing the absorption of the elements (Table 8), which enters in the structure of chlorophyll (Table 6). In vitro fertilization with Glomus mossae increases the effectiveness of photosynthesis due to symbiotic symbiosis of fungi that have the ability to convert unavailable phosphorus to the available phosphorus (Table 9). This will increase the growth of the host plant, which is provide Glomus mossae with carbon compounds and increasing the effectiveness of these Glomus mossae (Demir, 2004). Moreover, increasing the concentration of potassium (Table 10) in the plant is necessary to obtain the phytochemical response in the plant, which is positively reflected on the indicators of vegetative growth such as plant height (Table 7). The results are corresponding with previous studies (Hamdia and Shaddad, 2010; Joachim et al., 2009; Wang et al., 2008). The decrease in the studied indicators in Table 5 to 10 in the presence of the pathogen Fusariume may be due to the consumption of nutrients in the plant to compensate for the damage caused by the presence of fungus or decrease the efficiency of the Glomus mossae in release and availability of plant nutrients in soil or perhaps the plant has induced several mechanisms, including increased activity of defense enzymes and salicylic acid and increase in total phenols as well as mechanical resistance by increasing the thickness of the walls of cells with lignin. The mechanization by which the plant can grow under saline conditions to coexist with the Glomus mossae may be by reduced sodium absorption by the plant while increasing absorption of K, N, P and high chlorophyll content (Giri and Mukerji, 2004).

Table 4: Effect of Fusariume and Glomus mossae infection and soil salinity on percentage of infected root by Glomus mossae

\begin{tabular}{llll}
\hline Treatments|Soil EC $\left(\mathrm{dS} . \mathrm{m}^{-1}\right)$ & $2.64 \mathrm{dS} / \mathrm{m}^{-1}$ & $14.5 \mathrm{dS} / \mathrm{m}^{-1}$ & Mean treatments \\
\hline Control & 23.00 & 53.00 & 38.000 \\
F & 39.33 & 32.67 & 36.000 \\
G & 52.33 & 93.00 & 72.670 \\
FG & 45.00 & 60.67 & 52.830 \\
Mean soil salinity & 39.92 & 59.83 & 49.875 \\
\hline
\end{tabular}

$\mathrm{F}=$ Fusaruim graminearum $\mathrm{G}=$ Glomus mossae fungi

$\mathrm{FG}=$ Fusaruim graminearum + Glomus mossae fungi

L.S.D treatment $=2.931$ L.S.D soil salinity $=4.145$

$\mathbf{2 . 0 7 2}=$ interaction D.S.L

Table 5: Effect of Fusariume and Glomus mossae infection and soil salinity on percentage of plant germination

\begin{tabular}{llll}
\hline Treatments|Soil EC $\left(\mathrm{dS} . \mathrm{m}^{-1}\right)$ & $2.64 \mathrm{dS} / \mathrm{m}$ & $14.5 \mathrm{dS} / \mathrm{m}$ & Mean treatments \\
\hline Control & 72.3 & 62.3 & 67.30 \\
F & 28.0 & 24.3 & 26.20 \\
G & 75.7 & 71.0 & 73.30 \\
FG & 53.0 & 49.0 & 51.00 \\
Mean soil salinity & 56.2 & 52.7 & 54.45
\end{tabular}

$\mathrm{F}=$ Fusaruim graminearum $\mathrm{G}=$ Glomus mossae fungi

$\mathrm{FG}=$ Fusaruim graminearum + Glomus mossae fungi

L.S.D treatment $=6.44 \mathrm{~L}$. S.D soil salinity $=3.55$

L.S.D interactions $=9.10$

Table 6: Effect of Fusariume and Glomus mossae infection and soil salinity on chlorophyll content (spad)

\begin{tabular}{llll}
\hline Treatments $\mid$ Soil EC $\left(\mathrm{dS} . \mathrm{m}^{-1}\right)$ & $2.64 \mathrm{dS} / \mathrm{m}$ & $14.5 \mathrm{dS} / \mathrm{m}$ & Mean treatments \\
\hline Control & 18.78 & 16.33 & 17.55 \\
F & 14.33 & 13.67 & 14.00 \\
G & 32.33 & 24.00 & 28.17 \\
FG & 19.67 & 18.33 & 19.00 \\
Mean soil salinity & 21.11 & 18.25 & 19.68 \\
\hline
\end{tabular}

$\mathrm{F}=$ Fusaruim graminearum $\mathrm{G}=$ Glomus mossae fungi

$\mathrm{FG}=$ Fusaruim graminearum + Glomus mossae fungi

L.S.D treatment $=4.70$ L.S.D soli salinity $=3.324$

L.S.D interactions $=6.649$ 
Table 7: Effect of Fusariume and Glomus mossae infection and soil salinity on plant height (cm)

\begin{tabular}{llll}
\hline Treatments $\backslash$ Soil EC $\left(\mathrm{dS} . \mathrm{m}^{-1}\right)$ & $2.64 \mathrm{dS} / \mathrm{m}$ & $14.5 \mathrm{dS} / \mathrm{m}$ & Mean treatments \\
\hline Control & 25.00 & 20.00 & 22.50 \\
F & 12.67 & 12.00 & 12.33 \\
G & 40.00 & 25.00 & 32.50 \\
FG & 18.33 & 16.00 & 17.17 \\
Mean soil salinity & 24.00 & 18.25 & 21.125 \\
\hline
\end{tabular}

$\mathrm{F}=$ Fusaruim graminearum $\mathrm{G}=$ Glomus mossae fungi

$\mathrm{FG}=$ Fusaruim graminearum + Glomus mossae fungi

L.S.D treatment $=4.60$ L.S.D soil salinity $=3.256$

L.S.D interactions $=6.51$

Table 8: Effect of Fusariume and Glomus mossae infection and soil salinity on N\%

\begin{tabular}{llll} 
Treatments|Soil EC $\left(\mathrm{dS} . \mathrm{m}^{-1}\right)$ & $2.64 \mathrm{dS} / \mathrm{m}$ & $14.5 \mathrm{dS} / \mathrm{m}$ & Mean treatments \\
\hline Control & 2.067 & 1.833 & 1.950 \\
F & 2.033 & 1.367 & 1.700 \\
$\mathrm{G}$ & 3.233 & 1.900 & 2.567 \\
FG & 2.433 & 1.700 & 2.067 \\
Mean soil salinity & 2.442 & 1.700 & 2.071 \\
\hline
\end{tabular}

$\mathrm{F}=$ Fusaruim graminearum $\mathrm{G}=$ Glomus mossae fungi

$\mathrm{FG}=$ Fusaruim graminearum + Glomus mossae fungi

L.S.D treatment $=0.3250$ L.S.D soil salinity $=0.2298$

L.S.D interactions $=0.4596$

Table 9: Effect of Fusariume and Glomus mossae infection and soil salinity on P\%

\begin{tabular}{llll}
\hline Treatments $\mid$ Soil EC $\left(\mathrm{dS} . \mathrm{m}^{-1}\right)$ & $2.64 \mathrm{dS} / \mathrm{m}$ & $14.5 \mathrm{dS} / \mathrm{m}$ & Mean treatments \\
\hline Control & 0.230 & 0.150 & 0.190 \\
F & 0.153 & 0.046 & 0.100 \\
G & 0.326 & 0.216 & 0.272 \\
FG & 0.233 & 0.116 & 0.175 \\
Mean soil salinity & 0.236 & 0.136 & 0.184 \\
\hline
\end{tabular}

$\mathrm{F}=$ fusaruim graminearum $\mathrm{G}=$ Glomus mossae fungi

$\mathrm{FG}=$ fusaruim graminearum + Glomus mossae fungi

L.S.D treatment $=0.035$ L.S.D soil salinity $=0.025$

L.S.D interactions $=0.050$

Table 10: Effect of Fusariume and Glomus mossae infection and soil salinity on K\%

\begin{tabular}{llll}
\hline Treatments $\backslash$ Soil EC $\left(\mathrm{dS} . \mathrm{m}^{-1}\right)$ & $2.64 \mathrm{dS} / \mathrm{m}$ & $14.5 \mathrm{dS} / \mathrm{m}$ & Mean treatments \\
\hline Control & 2.533 & 1.867 & 2.200 \\
F & 2.267 & 1.333 & 1.800 \\
G & 3.500 & 2.167 & 2.833 \\
FG & 2.500 & 2.100 & 2.300 \\
Mean soil salinity & 2.700 & 1.867 & 2.283 \\
\hline
\end{tabular}

$\mathrm{F}=$ Fusaruim graminearum $\mathrm{G}=$ Glomus mossae fungi

$\mathrm{FG}=$ Fusaruim graminearum + Glomus mossae fungi

L.S.D treatment $=0.338$ L.S.D soil salinity $=0.239$

L.S.D interactions $=0.479$

\section{Conclusion}

The use of bio-fertilizers, especially the fungus of Glomus mossae, improves the nutritional status of plants, which is reflected positively on growth indicators such as germination percentage, plant content of chlorophyll, plant height and nutrient content (N, P and $\mathrm{K}$ ). Furthermore the inoclume with Glomus mossae is help plant to resistant to salt stress. The soil of $14.5 \mathrm{dS} . \mathrm{m}^{-1}$ has reduced the germination percentage and content of chlorophyll, plant height and nutrients. The triple interference between the studied factors did not show any increase in growth and nutrients. Further studies are recommended to understand the mechanisms of environmental stress conditions in the plant and to conduct studies on resistance mechanisms induced to resist pathogens (pathogens) using biotic agents.

\section{Acknowledgement}

The author extended thanks to the Centre of Soil Science and eater management Agriculture Research 
Directorate, Ministry of Science and Technology, Baghdad, Iraq for financial assistance of this work.

\section{Authors Contributions}

Ali Jabbar Abdulsada: Participated in all experiment. Sadeq J.H. Dwenee: Coordinated the data analysis. Naeem Saeed Dheyab, Doaa Abass Hanon and

Bara Hassan Hamza: Coordinated the mouse work. Wafaa Hadi Hasoon: Designed the research plan. Hadi Mahdi Aboud: Supervision this work.

\section{Ethics}

This article is original and contains unpublished material. The corresponding author confirms that all of the other authors have read and approved the manuscript and no ethical issues involved.

\section{References}

Adeleke, R.O. and J.O. Odedeji, 2010. Functional properties of wheat and sweet potato flour blends. Pak. J. Nutrit., 9: 535-538.

Agrios, G.N., 2005. Plant Pathology. 5th Edn., Academic Press, New York, USA, ISBN-10: 0120445654, pp: 952.

Alimi, A.C. and B. Ayawale, 2014. Effect of chemical pesticides on environmental pollution. Indian $\mathrm{J}$. Health Sci., 5: 124-128.

Azad, H.N., R.H. Mohammad, K. Farshid and S. Majid, 2012. The effects of $\mathrm{NaCl}$ stress on the physiological and oxidative situation of maize (Zea mays L.) plants in hydroponic culture. Curr. Res. J. Biol. Sci., 4: 17-22.

Bharathi, R., R. Vivekananthan, S. Harish, A. Ramanathan and R. Samiyappan, 2004. Rhizobacteria-based bio-formulations for the management of fruit rot infection in chillies. Crop Protect., 23: 835-843.

Bogale, M., 2006. Molecular characterization of Fusariume isolates from Ethiopia. PhD Thesis, University of Pretoria, Pretoria, South Africa.

Bovill, W.D., 2007. Identification, validation and pyramiding of quantitative trait loci for resistance to crown rot in wheat. MSc Thesis. The University of Southern Queensland.

Demir, S., 2004. Influence of arbuscular mycorrhiza on some physiological growth parameters of pepper. Turk J. Biol., 28: 85-90.

Dheyab, N.S., 2013. Using phosphate rock and superphosphate and adding fungal and bacterial fertilizers in the growth and yield of potatoes. $\mathrm{PhD}$ Thesis, College of Agriculture, University of Baghdad.
Gaur, A. and A. Adholya, 1994. Estimation of VAM spores in soil a modified method. Mycorrhiza News, 9: 10-11.

Gerdeman, J.W and T.H. Nicolson, 1963. Spores of mycorhizal endogone species extracted from soil by wet sieving and decanting. Trans. Brit. Mycol. Soc., 46: $235-244$.

Giovannetti, M. and B. Mosse, 1980. An evaluation of techniques for measuring vesicular arbuscular mycorrhizal infection in roots. New Phytol., 84: 489-500.

Giri, B. and K.G. Mukerji, 2004. Mycorrhizal inoculant alleviates salt stress in Sesbania aegyptiaca and Sesbania grandiflora under field conditions: Evidence for reduced sodium and improved magnesium uptake. Mycorrhiza, 14: 307-312.

Hamdia, M.A and M.A.K. Shaddad, 2010. Salt tolerance of crop plants. J. Stress Physiol. Biochem., 6: 64-90.

Hassan, A.A.M., 1999. Potato Production. 1st Edn., Vegetable Crops Series, Arabic Publishing House, Egypt.

Joachim, H., J.R. Makoi and P.A. Ndakidemi, 2009. The agronomic potential of Vesicular-Arbuscular Mycorrhiza (VAM) in cereals-legume mixtures in Africa. African J. Microbiol. Res., 3: 664-675.

Kormanik, P.P., W.C. Bryan and R.C. Schultz, 1980. Procedure and equipment for staining numbers of plant root samples for endomycorrhizal assays. Can. J. Microbiol., 26: 536-538.

Labetowicz, J., 1988. The chosen of analized method of soil, plant and fertilizer. SGGW-AR Warszawa, Poland.

Lauchli, A. and E. Epstein, 1990. Plant Responses to Saline and Sodic Conditions. In: Agricultural Salinity Assessment and Management, Wallendar, W.W. and K.K. Tanji (Eds.), American Society of Civil Engineers, ISBN-10: 0784473633, pp: 169-205.

Levitt, J., 1980. Responses of Plant to Environmental Stress: Water, Radiation, Salt and Other Stresses. 2nd Edn., Academic Press, ISBN-10: 0124455026, pp: 607.

McKinney, H.H., 1923. Influence of soil temperature and moisture on infection of wheat seedlings by Helminthosporium sativum. J. Agri. Res., 26: 195-217.

Miransari, M., 2011. Interactions between arbuscular mycorrhizal fungi and soil bacteria. Applied Microbiol. Biotechnol., 89: 917-930.

Mohammedi, S.M. and F.M. Al-Mohammadi, 2012. Statistics and design experiments Dar Osama for publication and distribution. Oman Jourdan. 
Naseby, D.C., J.A. Pascual and J.M. Lynch, 2000. Effect of biocontrol strains of Trichoderma on plant growth, Pythium ultimum population, soil microbial communities and soil enzyme. Activities. J. Applied Microbiol., 88: 161-169.

Phillips, J. and D.S. Hayman, 1970. Improved procedures for clearing roots and staining parasitic and Vesicular Arbuscular Mycorrhizal fungi for rapid assessment of infection. Trans. Br. Mycol. Soc., 55: 158-161.

Salman, N.D., 2013. The role of bio fertilizers in some biochemical and phylogenetic parameters in wheat plant under salt stress. J. Iraqi Agric. Sci.
Sheng, M., M. Tang, H. Chen, B.W Yang and F.F. Zhang et al., 2008. Influence of arbuscular Glomus mossae on photosynthesis and water status of maize plants under salt stress. Mycorrhiza, 18: 287-296.

Siddiqui, Z.A., M.S. Akhtar and K. Futai, 2006. Glomus Mossae: Sustainable Agriculture and Forestry. 1st Edn., Springer, Netherlands.

Wang, C., X. Li, J. Zhou, G. Wang and Y. Dong, 2008. Effects of arbuscular mycorrhizal fungi on growth and yield of cucumber plants. Commun. Soil Sci. Plant Anal., 39: 499-509.

DOI: $10.1080 / 00103620701826738$ 